МРНТИ 16.01.45

\author{
Егизбаева 3.С. ${ }^{1}$, Жандыкеева Г.Е. ${ }^{2}$, \\ 1,2 ст. преподаватель \\ Казахского государственного женского педагогического университета, \\ Казахстан, г. Алматы, e-mail: egiz.zam@mail.ru

\section{О ТЕХНОАОГИИ МАСТЕРСКИХ В ВУЗОВСКОМ ОБУЧЕНИИ РУССКОМУ ЯЗЫКУ}

В статье рассматривается методика применения технологии мастерских при обучении русскому языку в вузе. Охарактеризованы особенности Аанной технологии: продуктивный, творческий характер, сочетание индивидуальной, парной и групповой работы, отсутствие оценочности, критики и давления, совместный поиск решений. Автором статьи преАлагаются варианты проведения технологии педагогических мастерских на материале двух тем: «Художественный стиль. Стилевые и жанровые особенности» и «Публицистический стиль. Стилевые и жанровые особенности». Описываются все этапы мастерской и формы работы. В статье представлены такие методы и приемы, как построение ассоциативных рядов, работа с высказываниями и с текстом, создание ассоциативной картины, «Восстанови текст», рефлексия «Плюс-минус-интересно» и др., способствующие усвоению материала посредством выполнения практической работы. На конкретных примерах показано, что в зависимости от содержания и целей занятия алгоритмы мастерских могут варьироваться.

Ключевые слова: технология мастерских, сотрудничество, творческий характер, ассоциативность, комлективное взаимодействие, мастер, групповая работа, русский язык, методические приемы, работа с текстом.

Egizbaeva Z.S. ${ }^{1}$, Zhandykeyeva G.E. ${ }^{2}$,

1,2 Senior Lecturer of Kazakh State Women's Pedagogical University, Kazakhstan, Almaty, e-mail: egiz.zam@mail.ru

\title{
About technology workshops in teaching russian language in high school
}

The article discusses the technique of using technology workshops in teaching Russian in high school. The characteristics of this technology are characterized: productive, creative, a combination of individual, steam and group work, lack of evaluation, criticism and pressure, a joint search for solutions. The author of the article proposes options for conducting technology teaching workshops on the material of two topics: «The artistic style. Style and genre features» and «Publicistic style. Style and genre features». Describes all the stages of the workshop and the form of work. The article presents such methods and techniques as building associative rows, working with statements and text, creating an associative picture, «Recover the text», reflection «Plus or minus-interesting», etc., contributing to the assimilation of the material through the implementation of practical work. With specific examples, it is shown that, depending on the content of the topic and the objectives of the lesson, the algorithms of the workshops may vary.

Key words: technology workshops, cooperation, creative nature, associativity, collective interaction, master, group work, Russian language, teaching methods, work with the text. 


\author{
Егизбаева 3.С. ${ }^{1}$, Жандыкеева Г.Е. ${ }^{2}$, \\ Қазақ мемлекеттік қыздар педагогикалық университетінің \\ 1,2 аға оқытушысы, \\ Қазақстан, Алматы қ., е-mail: egiz.zam@mail.ru \\ Жоғары оқу орнында орыс тілін оқытудағы \\ шеберханалар технологиясы турамы
}

\begin{abstract}
Мақалада жоғары оқу орнында орыс тілін оқытудағы шеберханалар технологиясын пайдалану әдістемесі талқыланады. Бұл технологияның ерекшеліктері сипатталады: өнімді, шығармашылық сипаты, жеке, жұптық және топтық жұмысты үйлестіру, бағалаудың жоқтығы, сын мен қысым, шешімдерді бірлесіп іздеу. Мақаланың авторы екі тақырыптағы материа^ бойынша педагогикалық, шеберханалар технологиясын өткізу нұсқаларын ұсынады: «Көркемдік стиль. Стиль және жанрлық ерекшеліктері» және «Публицистикалық стиль. Стиль және жанрлық ерекшеліктері». Шеберхананың барлық кезеңдері және жұмыс түрлері сипатталады. Мақалада практикалық жұмысты орындау арқылы материалды меңгеруге ықпал ететін «Ассоциативті жолдар», мәтіндермен жұмыс жасау, ассоциативтік картина құрастыру, «Мәтінді қалпына келтіру», «П^юс-минус-қызықты» және т.б. әдістер мен тәсілдер көрсетілген. Нақты мысалдар арқылы тақырып мазмұны мен сабақтың мақсаттарына байланысты шеберханалардың алгоритмдері әртүрлі болуы мүмкін екені көрсетіледі.
\end{abstract}

Түйін сөздер: шеберханалар технологиясы, ынтымақтастық, шығармашылық сипат, ассоциациялылық, ұжымдық қарым-қатынас, шебер, топтық жұмыс, орыс тілі, оқыту әдістері, мәтінмен жұмыс.

\section{Введение}

Как известно, современный образовательный процесс в вузе предъявляет к вопросам методической организации учебной деятельности ряд условий. К ним относятся:

- проблемность;

- сотрудничество;

- коллективное взаимодействие;

- вовлечение обучаемых в постоянную активную деятельность;

- изменение модели преподавателя: соорганизатор, партнер, консультант (Ермолаева М.Г., 2014; Даутова О.Б., Иваньшина Е.В., 2015).

Данным требованиям, безусловно, отвечают развивающие технологии. Их применение является одной из важнейших тенденций в современном образовании. В частности, активно используются активные, творческие, проблемные, исследовательские, рефлексивные и другие эффективные способы учебной деятельности. Синтез перечисленных признаков присущ технологии педагогических мастерских.

\section{Экспериментальная часть}

В мастерской наиболее ярко проявляется, на наш взгляд, гуманизация учебного процесса (Белова Н.И., Мухина И.А., 1998; Соколова Э.С., 1997). Идейная сущность технологии мастерской можно образно определить словами Н.Бердяева:
«Я не согласен принять никакой истины иначе, как от свободы и через свободу».

Главное в мастерской - это атмосфера свободы и творчества. Это прослеживается на уровне концептуальных положений:

- Отказ от методов принуждения и форм подавления достоинства учеников.

- На мастерской предоставляется возможность каждому продвигаться к истине своим путем.

- Ученик имеет право на ошибку. Самостоятельное преодоление ошибки - путь к истине.

- Творческая деятельность - безоценочная деятельность.

- Мастер - для ученика, а не ученик для мастера.

- Сотрудничество, сотворчество, совместный поиск.

- Процесс познания гораздо важнее, ценнее, чем само знание.

- В отличие от урока, знания на мастерских не даются, а выстраиваются (Селевко Г.К., 2006; Белова Н.И., 2000).

В первых четырех положениях обозначена свобода в развитии ученика в процессе учебной деятельности. Подобное освобождение от давления позволяет учащимся раскрепоститься и раскрыть свои способности. Нет страха сделать что-то неправильно, не в соответствии с какимито стандартами. Все ученики способны.

В мастерской акцент делается на ценности развития личности, ее творческих и практи- 
ческих умений (Музиянова Л.А., 2003; Селевко Г.К., 2005).

Данная технология имеет общие черты с проблемным обучением. Новые знания в мастерской «добываются» путем поиска. Познание происходит через творчество.

Мастерская состоит из ряда взаимосвязанных этапов. Основные этапы или методические приемы мастерской: индукция, самоконструкция, социоконструкция, социализация, разрыв, рефлексия.

«Индукция» - это этап создания эмоционального настроя. В роли индуктора может функционировать образ, фраза, предмет, мелодия, текст, рисунок и т.д.

«Самоинструкция» - этоэтап индивидуальной работы над решением проблемы, созданием текста и т.д.

«Социоконструкция» предполагает построение указанных в самоинструкции элементов группой.

«Социализация» - это обнародование всего, что обсуждено, рассмотрено и сделано.

«Афиширование» - вывешивание работ учеников и мастера (текстов, рисунков, решений) в аудитории и ознакомление с ними.

«Разрыв»- внутренний эмоциональный конфликт, подвигающий к углублению в проблему, к поиску ответов.

«Рефлексия» - отражение чувств, ощущений, возникших у учащихся в ходе мастерской (Селевко Г.К., 2006; Ксензова Г.Ю., 2000).

Мастерская предполагает чередование индивидуальной, парной и групповой форм работы, что создает атмосферу сотрудничества, повышает уровень коммуникативной культуры обучающихся, облегчает познавательный процесс.

Еще одна особенность мастерских заключается в том, что работа в них основывается, как правило, на результатах духовной деятельности человечества, прежде всего на языке. Посредством языка, его красоты и богатства эффективно осуществляется формирование определенных умений и навыков.

Важную роль в мастерских выполняет побуждение к ассоциативному мышлению. Ассоциации «открывают» в какой-то мере работу воображения и тем самым содействуют развертыванию творческого процесса деятельности каждого (Мухина И.А., 2008).

В зависимости от содержания темы, этапа ее изучения и других факторов алгоритмы мастерских могут варьироваться.
Существует, как известно, несколько видов мастерских: мастерская ценностных ориентаций, мастерская творческого письма, мастерская по самопознанию, мастерская построения знаний.

В своей практике преподавания практического курса русского языка в вузе для студентовфилологов я применяла мастерскую ценностных ориентаций и мастерскую построения знаний.

Вот один из вариантов занятия, проведенного мною по этой технологии, при закреплении материала по теме «Художественный стиль. Стилевые и жанровые особенности».

Цели занятия:

- воспитание нравственных чувств, чувства сопереживания.

- развитие навыков анализа и определения особенностей художественного текста.

- совершенствование устной и письменной речи.

Ход мастерской:

Индуктор.

Macmep: Мы продолжаем изучать особенности художественного стиля, и сегодня у нас «Мастерская нравственных ценностей», в рамках которой мы будем анализировать художественные тексты.

Что мы будем сегодня рассматривать, вы определите сами, исходя из эпиграфа занятия.

Звучит эпиграф (аудиозапись эпиграфа):

Любовь всегда судит о людях с хорошей стороны, она удалена от злых умыслов, коварства и клеветы. Она извиняет слабости и старается укрепить человека в его силах. Она старается сделать добро каждому, всем прощает и всем служит. Она никогда не отказывается дать доброе наставление и всегда готова помочь примирить несогласие, охотнее претерпевает, нежели мстит, далека от присвоения чужого. Она всегда свободна и усердна к добру, постоянно удаляясь от зла. (Пенн Вильям)

Macmep: Итак, тема занятия «Любовь».

Macmep: Для проведения мастерской мы должны сформировать 3 группы.

1. Вопросы к группам: Приходилось ли вам в жизни любить кого-то?

Как и в чём выражалась ваша любовь?

2. Работа с толковыми словарями Даля, Ожегова, Ушакова (групповая работа).

Выберите несколько ключевых слов или словосочетаний, отражающих суть любви.

3. Построение ассоциативных рядов.

Какие ассочиачии возникают у вас в связи со словом ЛЮБОВЬ? 
Явления:

Музыка:

Образы:

Записать по 2 слова на каждый ряд.

Самоконструкция: учащиеся работают индивидуально (звучит Шопен «Музыка рая»).

Социоконструкция: ученики знакомят со своими ассоциациями товарищей по группе, идет обсуждение, ответы записываются на листке формата A4.

Социализация.

4. Работа с высказываниями о любви.

Высказывания:

«Всё побеждает любовь» (Вергилий).

« Любовь может изменить человека до неузнаваемости» (Катон).

«Любовь есть желание наслаждаться красотой. Красота же есть некое сияние, влекущее человеческую душу» (Петрарка).

Скажи, загадочный человек, кого ты любишь больше - отца, мать, сестру или брата?

- У меня нет ни отца, на матери, ни сестры, ни брата.

- А друзей?

- Не понимаю, о чем вы: смысл ваших слов от меня ускользает.

- А родину?

- Не знаю, в каких широтах она лежит.

- Красоту?

- Я рад бы ее полюбить, будь она бессмертной богиней.

- Золото?

- Ненавижу его, как вы ненавидите Бога.

- Так что же ты любишь, несуразный чужак?

- Люблю облака... облака, плывущие там... далеко...сказочные облака! (Ш. Бодлер. Парижский сплин).

Задание для групп: Выберите высказывание, которое ближе вам. Объясните почему? Какие черты художественного стиля наблюдаются в этих высказываниях?

5. Работа с текстами (звучит «Адажио» Т. Альбинони).

- Прочитать тексты и подчеркнуть слова и словосочетания, которые показывают, на ваш взгляд, состояние героев и природы.

- Выписать, что поразило (художественные фигуры - метафоры, сравнения и др.).

- Как отражает пейзаж состояние героев?

Тексты: К.Бальмонт «Есть в Русской природе усталая нежность», «Когда луна сверкнет во мгле ночной», «Камыши».

6. Мастер: Выполните следующую работу. Напишите небольшой рассказ, связанный с те- мой мастерской и нарисуйте картину на тему «Любовь».

Афиширование: Прочтение письменных работ и презентация рисунков.

Рефлексия. Что мы скажем друг другу, прощаясь?

Следующий пример - мастерская построения знаний на тему «Публицистический стиль. Стилевые и жанровые особенности».

Ход мастерской:

Приветствие мастера.

Индуктор. Стихотворение А. Дементьева «Никогда ни о чем не жалейте вдогонку».

- О чем это стихотворение?

- Какие ассоциации вызвало это стихотворение?

- Сравните свои ассоциации с моими: призыл, побуждение к действию, доброта, вера.

- Почему в стихотворении повторяется глагол не жалейте?

- Рассмотрите значения глагола не жалейте в стихотворении и сравните их со словарными статьями в двух толковых словарях русского языка.

- Какие предложения по цели высказывания в нем доминируют? Почему?

Macmep: Сегодня мы будем рассматривать особенности публицистического стиля. Стихотворение относится к художественному стилю, но в нем есть такие черты публицистического стиля, как побудительный характер, который проявляется как на уровне формы, так и на уровне содержания.

Задание для групn. Определите, в каком предложении текста наиболее полно отражена основная мысль?

1) Человек осуществляет себя и утверждает делом. (2) Поэтому выбор дела - это выбор судьбы. (3) Путь к величию человека лежит в высочайшем его призвании, которое выражается в одном: работать, работать, работать. (4) Ибо никто не сделает за тебя того, что должен сделать ты сам. (5) С младых лет должно усвоить, что иждивенчество унизительно. (6) Не живите ожиданием благ от других, а делайте все, что в ваших силах. (7) В противном случае вы или гость за чужим столом, или дикий вьюн, бессмысленно обвивающий древо жизни. (8) Работа имеет высший смысл - это путь по-настоящему познать самого себя, свои возможности, утвердить себя в жизни. (9) Это и путь самосовершенствования, ведь человек начинается именно с его отношения к труду.

(По Ю.В. Бондареву) 
Самоконструкция. Исходя из содержания данного текста, закончите выделенные предложения. Сравните свой вариант предложений с оригиналом.

Какие наблюдаются языковые особенности в данном тексте. Проанализируйте лексический, морфологический и синтаксический уровни.

Позади годы отрочества. Ты был в конфликте чуть ли не со всем миром. То мир тебя не понимал, то ты его не понимал. Разрыв между мечтой и действительностью приводил в недоумение. Ты не научился еще реально смотреть на мир, взвешивать свои силы.

Теперь тебе предстоит научиться соотносить мечту со своими возможностями, понять: чем больше человек знает, тем...Истинное счастье - удел ... Значит, учиться надо не потому, что надо, а для интереса в жизни.

Ради чего вообще пришли мы на землю? Какой мы след оставим после себя? Если ты подумаешь и ответишь на эти вопросы, - значит, ты уже имеешь жизненную позицию, ты всерьез решил оставить после себя добрые дела. А добрых дел очень много: ...

Л. Толстой писал: «Праздный ум - это ...». Не оставляйте ума и рук в праздности! Сегодня же, сейчас же заставьте себя сделать себя тот правильный шаг, который вы откладываете, повторите это завтра, послезавтра, найдите разумное сочетание между «хочу» и «надо» - и вы ...

(По А. Алексеевой)

Социоконструкция.

Социализация.

Задание для групп: Сравните первый текст с приведенным ниже. Охарактеризуйте их общие стилистические особенности.

Из непроглядных временных далей течет поток рода людского, именуемый Историей. Он несет нас через наше сегодня дальше, в неведомое.

В неведомое? Ой нет, не совсем! Далекое проступает уже сейчас, только надо уметь его видеть - великое через малое, в падающем яблоке - закон всемирного тяготения.

Кто в 1820 году обратил внимание на сообщение Эрстеда, что стрелка компаса резко отклонилась к проволоке, по которой пропущен ток?.. Людей тогда волновала судьба Наполеона, доживавшего последние дни на острове Святой Елены, убийство герцога Беррийского. А стрелка компаса... экая, прости господи, чепуха. Но от нее вздрогнула История, началась новая промышленная эра, электричество вошло в жизнь и изменило ее, изменился мир, изменились мы сами.
А щепотка урановой соли, случайно засветившая фотопластинку Беккереля... А «безумные» прожекты скромного учителя из Калуги вырваться из объятия Земли!..

Течет поток рода людского. Куда? Какие силы гонят его? Безвольные ли мы рабы этих фатальных сил, или у нас есть возможность както их обуздать? Мучительные вопросы бытия всегда вызывали страх перед будущим. Он прорывался в легендах о всемирном потопе, хоронящем под собой человечество, в кошмарах откровения от Иоанна, в жестоких расчетах Мальтуса. И хотя активная жизнедеятельность людей побеждала этот страх, но тревога за свои судьбы не исчезала и загадки бытия не становились менее мучительными.

(По В. Тендрякову)

Афиширование.

Рефлексия «Плюс-минус-интересно». Это упражнение можно выполнять как устно, так и письменно, в зависимости от наличия времени. При письменном выполнении заполняется таблица из трех граф.

В графу «П» - «плюс» записывается все, что понравилось на занятии, информация и формы работы.

В графу «М»- «минус» записывается все, что не понравилось на занятии, осталось непонятным.

В графу «И» - «интересно» студенты вписывают все любопытные факты, о которых узнали и что еще хотелось бы узнать по данной теме.

Весьма эффективно, по нашему мнению, использование методических приемов мастерской и при изучении грамматического материала. Например, при рассмотрении особенностей художественного текста можно применить следующий вариант мастерской:

Индуктор. Мастер: Я держу в руках зажженную свечу. Какие ассоциации она у вас вызывает?

Самоконструкция.

Социоконструкция.

1. Сравните свои ассоциации с моими: $C$ веча - свет. Свет - это знания. Свеча - это свет истины.

Мастер: Учитесь, стремитесь к знаниям. Нет предела совершенству.

Tот, кто ничего не знает и знает, что ничего не знает, тот знает больше, чем тот, кто ничего не знает и не знает, что ничего не знает.

Омар Хайям сказал:

Много лет размышилял я над жизнью земной. Непонятного нет для меня под луной.

Мне известно, что мне ничего не известно. 
Вот последняя правда, открытая мной.

2. Какой еще афоризм подобного содержания вы знаете?

3. Попробуйте определить, какой грамматический материал мы будем рассматривать. Подсказка содержится в первом афоризме.

4. Вы любите поэзию? Что для вас поэзия? Ответьте на этот вопрос, продолжив предложение: Поэзия - это мир, ...

Сколько грамматических основ в составленном вами предложении? (Если составляется простое осложненное, преобразовывается в СПП).

3.Прочитайте отрывки из стихотворений известных поэтов и скажите, какое вам больше понравилось? Почему? Охарактеризуйте его с точки зрения структуры.

\section{4. Работа с текстом.}

Милосердие приветливость доброта делает человека красивым. Лицо человека которое часто искажается злобой становится безобразным.
Дело в том что злая реакция на окружающее грубость и непонимание окружающего - это признак душевной и духовной слабости неспособности жить.

Человек который не умеет понять другого обедняет свою жизнь и мешает жить другим. (Д.С. Лихачёв)

1) Расставьте знаки препинания.

2) Определите основную мысль текста.

3)Выполните синтаксический разбор предложения: Человек, который не умеет понять другого, обедняет свою жизнь и мешает жить другим.

4) Определите стиль и тип речи.

Социализация.

Разрыв.

5. Быстро прочитывая грамматические формулировки, отмечайте знаком + в пустом квадрате справа лишь те утверждения, которые являются истинными (карточки).

\begin{tabular}{|c|c|c|}
\hline № & Утверждения & + \\
\hline 1 & Сложноподчинённое предложение состоит из двух простых предложений & \\
\hline 2 & $\begin{array}{l}\text { В состав сложноподчинённого предложения входят главное предложение и одно или несколько } \\
\text { придаточных. }\end{array}$ & \\
\hline 3 & Простые предложения в составе сложноподчинённого всегда равноправны. & \\
\hline 4 & Придаточное предложение с главным связано сочинительной или подчинительной связью. & \\
\hline 5 & $\begin{array}{l}\text { В роли средств связи в сложноподчинённом предложении выступают подчинительные союзы или союзные } \\
\text { слова. }\end{array}$ & \\
\hline 6 & Союзные слова отвечают на вопросы и выполняют синтаксическую роль. & \\
\hline 7 & $\begin{array}{l}\text { Придаточные в сложноподчинённом предложении в зависимости от значения делятся на изъяснительные, } \\
\text { определительные, обстоятельственные. }\end{array}$ & \\
\hline 8 & Вид придаточного предложения определяют по союзу или союзному слову. & \\
\hline 9 & Вид придаточного предложения определяют по вопросу, поставленному от главного предложения. & \\
\hline 10 & Главное предложение от придаточного на письме обычно отделяется запятой, а в устной речи паузой. & \\
\hline 11 & $\begin{array}{l}\text { В сложноподчинённых предложениях с несколькими придаточными, могут быть такие типы подчинения: } \\
\text { однородное, параллельное и последовательное. }\end{array}$ & \\
\hline 12 & $\begin{array}{l}\text { В сложноподчинённых предложениях с несколькими придаточными, могут быть такие типы подчинения: } \\
\text { сочинительное, подчинительное и бессоюзное. }\end{array}$ & \\
\hline
\end{tabular}

Рефлексия. Представьте результаты своей работы на сегодняшнем занятии в виде размышлений о том:

\begin{tabular}{|c|l|c|}
\hline № & Что я узнала на занятии & Ответ в свободной форме \\
\hline 1 & О структуре и видах СПП в различных стилях речи & \\
\hline 2 & Какое значение это знание имеет для меня? & \\
\hline
\end{tabular}




\section{Результаты и обсуждение}

Наш опыт применения мастерских на занятиях по практическому курсу русского языка показывает, что это продуктивная и интересная форма учебной деятельности. Студенты мотивированы, проявляют высокую степень заинтересованности, работают с увлечением и раскрывают свой творческий потенциал. Организация педагогических мастерских повышает уровень обученности студентов, позволяет в занимательной, нетрадиционной форме решать конкретные, практические учебные задачи и формировать основные виды коммуникативной компетенции.

\section{Заключение}

Технология педагогических мастерских позволяет осуществить саморазвитие студента, способствует активности студентов, усвоению материала посредством выполнения практической работы, повышает интерес к процессу обучения, развивает творческое мышление и коммуникативные навыки.

\section{Литература}

Ермолаева М.Г. Интерактивные методики в современном образовательном процессе. - М.: Просвещение, 2014. - 42 с. Современные педагогические технологии основной школы в условиях ФГОС / Даутова О.Б., Иваньшина Е.В., Ивашедкина О.А., Казачкова Т.Б., Крылова О.Н., Муштавинская И.В. - СПб.: КАРО, 2015. - 176 с.

Педагогические мастерские: теория и практика / Сост. Н.И. Белова, И.А. Мухина.- СПб.: Новое образование, 1998. $318 \mathrm{c}$.

Педагогические мастерские: Франция, Россия / Под ред. Э.С. Соколовой. - М.: Новая школа, 1997. - 128 с.

Селевко Г.К. Энциклопедия образовательных технологий. - В 2-х т. - Т. 1., М.: НИИ школьных технологий, 2006. $816 \mathrm{c}$.

Белова Н.И. Педагогическая мастерская как средство развития личности участников образовательной деятельности: дис. ... канд. пед. наук. - СПб., 2000. - 216 с.

Музиянова Л.А. Творческие мастерские // Русский язык в школе. - 2003. - № 6. - С. 19-22.

Селевко Г.К. Альтернативные педагогические технологии. - М.: НИИ школьных технологий, 2005. - 224 с.

Ксензова Г.Ю. Перспективные школьные технологии. - М.: Пед. общество России, 2000. - 224 с.

Мухина И.А. Что такое педагогическая мастерская? // Режим доступа:http://1piar.ru/folio/folio-82842.php

\section{References}

Belova N.I., Muhina I.A. (1998) Pedagogicheskie masterskie: teoriya I praktika. SPb.:Novoe o/brazovanie, 1998. 318 p. (In Russian)

Belova N.I. (2000) Pedagogicheskaya masterskaya kak sredstvo razvitiya lichnosti uchastnikov obrazovatelnoi deyatelnosti: dis. ... kand. ped. nauk. SPb., 2000. 216 p. (In Russian)

Belova N.I. (2000) Pedagogicheskaya masterskaya kak sredstvo razvitiya lichnosti uchastnikov obrazovatelnoi deyatelnosti: dis. ... kand. ped. nauk. SPb., 2000. 216 p. (In Russian)

Dautova O.B., Ivanshina E.B., Ivashedkina O.A., Kazachkova T.B., Krylova O.N., Mushtavinskaya I.V. (2015) Sovremennye pedagogicheskie tehnologii osnovnoishkolyvusloviyahFGOS.Sankt-Peterburg: KARO, 2015. 176 p. (In Russian)

Ksenzova G.Yu. (2000) Perspektivnye shkolnye tehnologiyi. M.: Ped. Obchestvo Rossiyi, 2000. 224 p. (In Russian)

MuziyanovaL.A. (2003) Tvorcheskiyemasterskie.[Russkiyazykvshkole]. 2003. No 6. Pp. 19-22. (In Russian)

Muhina I.A. Chtotakoye pedagogicheskaya masterskaya? Retrieved fromhttp://1piar.ru/folio/folio-82842.php(In Russian)

Sokolova E.S. (1997) Pedagogicheskiemasterskie: Frantciya, Rossiya. M.: Novayashkola, 1997. 128 p. (In Russian)

Selevko G.K. (2006) Antsiklopediya obrazovatelnyh tehnologiy. V 2-ht. T.1., M.: NIIshkolnyhtehnologiy, 2006.816 p. (In Russian)

Selevko G.K. (2005) Alternativnye pedagogicheskie tehnologii. M.: NIIshkolnyh tehnologiy, 2005. 224 p.(In Russian) 